\title{
Selection of an efficient Arbuscular Mycorrhizal fungus for inoculating Broom Grass (Tysandaena maxima)
}

\author{
N. Nikhil Sai ${ }^{1}$, R. Ashwin ${ }^{1}$, D.J. Bagyaraj ${ }^{1 *}$ and R. Venugopala Rao ${ }^{2}$ \\ ${ }^{I}$ Centre for Natural Biological Resources and Community Development (CNBRCD), 41 RBI Colony, Anand Nagar, Bangalore \\ 560024, Karnataka \\ ${ }^{2}$ Laya Resource Centre, Yendada, Visakhapatnam 530045 \\ *Corresponding authorEmail:djbagyaraj@gmail.com
}

(Submitted on August 18, 2019; Accepted on October 20,2019)

\begin{abstract}
Thysanolaena maxima (broom grass) is an ever green non-timber forest produce species. Pot experiment was conducted to screen and select the efficient arbuscular mycorrhizal fungi (AMF) for inoculating broom grass. Screening was done with nine different species of AMF (Funneliformis caledonium, Acaulospora laevis, Rhizophagus fasciculatus, Claroideoglomus etunicatum, Gigaspora margarita, Glomus bagyarajii, Funneliformis mosseae, Rhizophagus intraradices and Ambispora leptoticha). Plant parameters like height, stem girth, biovolume index, total plant dry weight, and mycorrhizal parameters like root colonization, spore number in the root zone soil, etc. have been recorded according to the standard procedures. Based on the important plant parameters like bio-volume index, total plant dry weight, and phosphorus uptake, it is concluded that Claroideoglomus etunicatum is the best AMF for inoculating broom grass.
\end{abstract}

KEYWORDS: AMF, Thysanolaena maxima, biovolume index, Claroideoglomus etunicatum

\section{INTRODUCTION}

AMF are ubiquitous, found in all types of soil, climate and environment all over the world (Garcés-Ruiz et al., 2017). More than $80 \%$ of the terrestrial plants form association with mycorrhizal fungi and improve the ability of plants to cope with environmental stresses and facilitate uptake of diffusion limited nutrients (Surendran and Vani, 2013; Bonfante, 2018).These fungi also produce plant growth promoting substances like indole acetic acid, gibberellic acid and cytokinin which greatly influence root growth and proliferation (Ortas, 2010; Bagyaraj, 2014). Finely branched arbuscules and swollen vesicles are developed in the root of host plant, where arbuscules act as the site of nutrient exchange between the fungus and the plant (Berruti et al., 2016). AMF also enhance the number and activity of beneficial soil organisms like nitrogen fixers and phosphate solubilizers in the rhizosphere with consequential beneficial effect on plant growth (Bagyaraj, 2015; Hashem et al., 2016). Though AMF are not host specific but they exhibit host preference thus suggesting the need for selecting an efficient AMF for a particular host, as evidenced by earlier studies (Thilagar and Bagyaraj, 2015; Ashwin et al., 2019). Several factors influence the rate of success of inoculation in improving plant growth like AMF species compatibility with the host, interaction with other soil organisms, environment in the target niche, etc. Because of the difficulty in mass production of AMF, the best way to utilize AMF for crop production would be to concentrate on crops which are normally grown on nursery beds, root trainers or poly bags, where they could easily be inoculated with desired AMF.

Thysanolaena maxima popularly known as 'broom grass' or 'tiger grass' is an ever green non-timber forest produce species. It belongs to the family Poaceae and grows wildly in hilly areas, of North East India (especially Meghalaya) and in Andhra Pradesh. The plant helps to reduce soil erosion and their leaves can be used as fodder for cattle and does not require much labour input as other crops. The inflorescence that is about $30-90 \mathrm{~cm}$ long resembles a foxtail and used as broom in every Indian household (Ramanaiah et al., 2012).
The brooms of this grass are more durable than those made from other plants such as Cocos nucifera and Phragmites species. Local tribes use stem of this plant as wall building materials and is also used as raw material in paper industry. Due to its huge demand throughout the country the stocks has been depleting fast since no cultivation has yet been taken up commercially till recently. Selling of broom generates local empowerment for local tribes. In recent years the tribal communities residing in high altitude regions of Andhra Pradesh are dependent on surrounding forests for their livelihoods and broom grass is a major crop depended upon. Recently they have started cultivating broom grass in hill slopes either as an inter crop or as a sole crop. The information available on the method of cultivation of this crop is scanty. In the present investigation a glass house experiment was undertaken to screen and select an efficient AMF that can be used as an inoculant to promote the growth of broom grass.

\section{MATERIAL AND METHODS}

The poly house experiment was conducted at Centre for Natural Biological Resources and Community Development (CNBRCD), Bangalore. The rhizome of broom grass used for planting in the present study was obtained from Laya Resource Centre, Vishakapatanam, Andhra Pradesh. The substrate used for growing plants in the study was red sandy loam soil (Alfisol): sand: vermicompost mix in 1:1:0.25 v/v/v ratio. Polybags of the size $26 \times 14 \mathrm{~cm}$ were filled with the substrate to hold $3.5 \mathrm{~kg}$ substrate. The substrate mix had a $\mathrm{pH}$ of 6.0. Based on the results of earlier studies on other crop plants the following 9 AMF species were selected as inoculants; Funneliformis caledonium, Acaulospora laevis, Rhizophagus fasciculatus, Claroideoglomus etunicatum, Gigaspora margarita, Glomus bagyarajii, Funneliformis mosseae, Rhizophagus intraradices and Ambispora leptoticha.

AMF cultures were maintained in the germplasm bank of CNBRCD, Bangalore using vermiculite: perlite: soilrite 3:1:1 $\mathrm{v} / \mathrm{v} / \mathrm{v}$ ratio as the substrate and Rhodes grass (Chloris gayana) as the host. Finely chopped roots from 75 day old plants along with the substrate was air-dried and used as the mycorrhizal 
inoculum. A planting hole was made at the centre of each bag filled with the substrate. Ten grams of AMF inoculum was added to the planting hole as per the treatment and each treatment was replicated 6 times. Uninoculated treatment received washed AMF inoculum suspension passed through a $45 \mu \mathrm{m}$ sieve which contained associate microorganisms but not AMF propagules at the rate of $10 \mathrm{~mL}$ per plant. The plants were maintained in a poly house and watered when necessary.

The plants were harvested 7 months after planting (MAP). The plant height was measured from soil surface to the growing tip of the plant and stem girth was measured 1 centimeter above the soil surface using digital Vernier Calipers before harvesting. Biovolume index (BI) of the plant was calculated by the formula suggested by Hatchell et al. (1985). Shoot, root and total plant dry weight were determined after drying the sample at $60^{\circ} \mathrm{C}$ to a constant weight in a hot air oven. The dry weight of shoot and root was determined after drying the sample to a constant weight. The phosphorus $(\mathrm{P})$ content in the shoot and root was determined by the vanado-molybdate phosphoric acid yellow colour method (Jackson, 1973). The per cent mycorrhizal root colonization was determined by staining fine roots with trypan blue (Philips and Hayman, 1970) and estimated adopting gridline intersect method (Giovannetti and Mosse, 1980). The AMF spore numbers in the root zone soil was determined by wet sieving and decantation method (Bagyaraj and Sturmer, 2008). Statistical analysis was done by subjecting the data to analysis of variance (ANOVA) followed by Duncan's multiple-range test to differentiate the significant difference between different treatments at the probability level of $\mathrm{P} \leq 0.05$ using statistical software AGRES version 3.01.

\section{RESULTS}

Plants varied in their response to AMF inoculation. In general, plants inoculated with AMF had significantly higher growth compared to uninoculated plants. Plant height was significantly higher in C. etunicatum treated plants and was on par with all other treatments except $R$. fasciculatus treated plants and uninoculated control plants. Stem girth was found to be significantly higher in plants inoculated with $R$. intraradices but statistically on par with all other treatments except $R$. fasciculatus treated plants and the uninoculated control treatment.

The biovolume index was significantly high in plants inoculated with $C$. etunicatum but not differing from other inoculated treatments except $R$. fasciculatus treatment and uninoculated treatment (Table 1). The shoot dry weight was significantly more in all the inoculated treatments except in uninoculated control, maximum being in the treatment with G. bagyarajii. The root dry weight was significantly higher in plants inoculated with $C$. etunicatum and $F$. caledonium compared to all other inoculated treatments and the least root dry weight was observed in the uninoculated treatment. More or less similar trend was observed in the total plant dry weight, highest being recorded in C. etunicatum treated plants closely followed by $F$. caledonium inoculated plants (Table 1).
Table 1: Effect of AMF inoculation on plant parameters of broom grass

\begin{tabular}{|l|c|c|c|c|c|c|}
\hline Treatment & $\begin{array}{c}\text { Height } \\
\text { (cm/ } \\
\text { plant) }\end{array}$ & $\begin{array}{c}\text { Stem } \\
\text { girth } \\
\text { (mm/ } \\
\text { plant) }\end{array}$ & $\begin{array}{c}\text { Bio- } \\
\text { volume } \\
\text { Index }\end{array}$ & $\begin{array}{c}\text { Shoot dry } \\
\text { weight } \\
\text { (g/plant) }\end{array}$ & $\begin{array}{c}\text { Root dry } \\
\text { weight } \\
\text { (g/plant) }\end{array}$ & $\begin{array}{c}\text { Total plant } \\
\text { dry weight } \\
\text { (g/plant) }\end{array}$ \\
\hline Uninoculated control & $18.45^{\mathrm{c}}$ & $3.54^{\mathrm{c}}$ & $65.06^{\mathrm{c}}$ & $18.62^{\mathrm{b}}$ & $13.92^{\mathrm{g}}$ & $32.54^{\mathrm{c}}$ \\
\hline Funneliformis caledonium & $25.29^{\mathrm{ab}}$ & $5.56^{\mathrm{ab}}$ & $145.96^{\mathrm{a}}$ & $26.45^{\mathrm{a}}$ & $30.39^{\mathrm{a}}$ & $56.84^{\mathrm{a}}$ \\
\hline Acaulospora laevis & $26.08^{\mathrm{ab}}$ & $5.31^{\mathrm{ab}}$ & $139.39^{\mathrm{ab}}$ & $24.26^{\mathrm{a}}$ & $27.00^{\mathrm{b}}$ & $51.26^{\mathrm{b}}$ \\
\hline Rhizophagus fasciculatus & $22.11^{\mathrm{bc}}$ & $4.65^{\mathrm{bc}}$ & $104.47^{\mathrm{b}}$ & $23.69^{\mathrm{a}}$ & $23.69^{\mathrm{c}}$ & $47.38^{\mathrm{bc}}$ \\
\hline Claroideoglomus etunicatum $^{\mathrm{b}}$ & $27.00^{\mathrm{a}}$ & $5.55^{\mathrm{ab}}$ & $149.78^{\mathrm{a}}$ & $24.68^{\mathrm{a}}$ & $32.87^{\mathrm{a}}$ & $57.55^{\mathrm{a}}$ \\
\hline Gigaspora margarita & $25.67^{\mathrm{ab}}$ & $4.98^{\mathrm{ab}}$ & $128.15^{\mathrm{ab}}$ & $23.98^{\mathrm{a}}$ & $19.59^{\mathrm{de}}$ & $43.57^{\mathrm{cd}}$ \\
\hline Glomus bagyarajii & $24.88^{\mathrm{ab}}$ & $5.14^{\mathrm{ab}}$ & $127.76^{\mathrm{ab}}$ & $26.96^{\mathrm{a}}$ & $20.86^{\mathrm{cd}}$ & $47.82^{\mathrm{bc}}$ \\
\hline Funneliformis mosseae & $24.98^{\mathrm{ab}}$ & $5.41^{\mathrm{ab}}$ & $135.47^{\mathrm{b}}$ & $25.01^{\mathrm{a}}$ & $17.14^{\mathrm{et}}$ & $42.15^{\mathrm{d}}$ \\
\hline Rhizophagus intraradices & $24.75^{\mathrm{ab}}$ & $5.90^{\mathrm{a}}$ & $144.33^{\mathrm{a}}$ & $24.40^{\mathrm{a}}$ & $19.44^{\mathrm{de}}$ & $43.84^{\mathrm{cd}}$ \\
\hline Ambispora leptoticha & $26.70^{\mathrm{a}}$ & $5.62^{\mathrm{ab}}$ & $148.78^{\mathrm{a}}$ & $25.13 \mathrm{a}$ & $15.68^{\mathrm{fg}}$ & $40.81^{\mathrm{d}}$ \\
\hline SED & 1.98 & 0.58 & 19.39 & 1.86 & 1.54 & 2.40 \\
\hline CD (0.05) & 3.99 & 1.17 & 39.19 & 3.73 & 3.09 & 4.83 \\
\hline Values in each column followed by the same letter are not significantly different at $\mathrm{P} \leq 0.05$ level \\
\hline
\end{tabular}

The root $\mathrm{P}$ content was significantly higher in plants inoculated with $C$. etunicatum when compared to the other inoculated treatments and control. The shoot $\mathrm{P}$ content was highest in $C$. etunicatum treatment and not significantly differing from A. laevis, F. caledonium and G. bagyarajii treated plants. The least $\mathrm{P}$ content was observed in the uninoculated control plants. Highest root $\mathrm{P}$ content was recorded in plants inoculated with $C$. etunicatum which differed significantly from all the other inoculated and uninoculated treatments.

All the inoculated treatments showed significantly higher per cent mycorrhizal root colonization compared to uninoculated treatment, highest colonization being recorded in plants inoculated with C. etunicatum. Mycorrhizal spore numbers in the root zone soil was also more in all the inoculated treatments compared to the uninoculated treatment, highest number occurring in the treatment with A. leptoticum (Table 2).

Table2: Effect ofAMF inoculation on mycorrhizal and plantparameters.

\begin{tabular}{|c|c|c|c|c|}
\hline Treatment & $\begin{array}{l}\text { Mycorrhizal root } \\
\text { colonization (\%) }\end{array}$ & $\begin{array}{c}\text { Spore number/ } \\
50 \mathrm{~g} \text { of root } \\
\text { zone soil } \\
\end{array}$ & $\begin{array}{c}\begin{array}{c}\text { Shoot } P \\
\text { content } \\
\text { (mg/ plant) }\end{array} \\
\end{array}$ & $\begin{array}{c}\text { Root P } \\
\text { content } \\
\text { (mg/ plant) }\end{array}$ \\
\hline Uninoculated control & $11.11^{\mathrm{c}}$ & $130^{\mathrm{h}}$ & $114.5^{\mathrm{e}}$ & $343.5^{\mathrm{h}}$ \\
\hline Funneliformis caledonium & $80.00^{\mathrm{ab}}$ & $180^{\circ}$ & $154.5^{\mathrm{ab}}$ & $549.6^{b}$ \\
\hline Acaulospora laevis & $68.89^{b}$ & $160^{\mathrm{e}}$ & $157.5^{\mathrm{a}}$ & $532.4^{\mathrm{de}}$ \\
\hline Rhizophagus fasciculatus & $82.22^{\mathrm{ab}}$ & $145^{\mathrm{g}}$ & $147.4^{\mathrm{bc}}$ & $509.5^{1}$ \\
\hline $\begin{array}{l}\text { Claroideoglomus } \\
\text { etunicatum }\end{array}$ & $93.33^{\mathrm{a}}$ & $150^{\mathrm{f}}$ & $160.2^{\mathrm{a}}$ & $589.6^{\mathrm{a}}$ \\
\hline Gigaspora margarita & $91.11^{\mathrm{ab}}$ & $150^{\mathrm{T}}$ & $139.8^{\mathrm{c}}$ & $498.0^{\mathrm{g}}$ \\
\hline Glomus bagyarajii & $80.00^{\mathrm{ab}}$ & $165^{\mathrm{d}}$ & $154.5^{\mathrm{ab}}$ & $515.25^{\mathrm{t}}$ \\
\hline Funneliformis mosseae & $77.78^{\mathrm{ab}}$ & $150^{\mathrm{I}}$ & $145.9^{\mathrm{c}}$ & $526.7^{\text {be }}$ \\
\hline Rhizophagus intraradices & $82.22^{\mathrm{ab}}$ & $185^{\mathrm{b}}$ & $145.9^{\mathrm{c}}$ & $543.87^{\mathrm{bc}}$ \\
\hline Ambispora leptoticha & $84.44^{\mathrm{ab}}$ & $195^{\mathrm{a}}$ & $125.9^{\mathrm{d}}$ & $538.15^{\mathrm{cd}}$ \\
\hline SED & 10.97 & 1.75 & 4.08 & 4.08 \\
\hline CD (0.05) & 22.88 & 3.64 & 8.52 & 8.52 \\
\hline
\end{tabular}

\section{DISCUSSION}

In the present study inoculation with AMF significantly enhanced plant growth compared to uninoculated control plants. Increased plant growth because of AMF inoculation is well documented (Thilagar and Bagyaraj, 2015; Ashwin et al., 2019). Of the various inoculated treatments studied inoculation with C. etunicatum significantly enhanced plant height, BI and total plant dry weight of broom grass. Higher BI value indicates higher quality of plants (Hatchell et al., 1985). It has been reported earlier that inoculation with $C$. etunicatum significantly enhanced BI of ashwagandha (Anuroopa and Bagyaraj, 2015) and tulasi (Jyothi and Bagyaraj, 2016). In case of total plant dry weight inoculation 
with C. etunicatum significantly enhanced total plant dry weight compared to other inoculated treatments and uninoculated control plants. This is in conformity with the earlier report of Anuradha et al. (2012) who observed that inoculation with C. etunicatum significantly enhanced the dry weight of two bamboo species.

The shoot and root $\mathrm{P}$ content was also higher in plants inoculated with AMF, maximum being in plants inoculated with $C$. etunicatum. Various mechanisms have been suggested for increased $\mathrm{P}$ uptake by mycorrhizal plants like mycorrhizal hyphae exploring greater volume of soil for diffusion limited nutrients like $P$ away from the root, effective $P$ acquisition by external hyphae by production of phosphatases and $\mathrm{Pi}$ transporters, and smaller radii of absorptive system (Bagyaraj et al. 2015; Bücking and Kafle, 2015; Ashwin et al., 2018).

C. etunicatum inoculated plants showed higher per cent mycorrhizal root colonization. Earlier workers have reported that inoculation with $C$. etunicatum increased the per cent mycorrhizal root colonization and spore number in the root zone soil (Ashwin et al., 2019). Higher root colonization allows more fungal host contact, more exchange of nutrients and hence better plant growth. In the present study, there was a positive correlation between mycorrhizal root colonization and plant growth parameters supporting the observations made by earlier workers (Thilagar and Bagyaraj, 2015; Bhale, 2018).

Earlier workers have screened several AMF in order to select the best for inoculating a particular crop like chilly (Thilagar and Bagyaraj, 2015), tulasi (Jyothi and Bagyaraj, 2016) and soybean (Ashwin et al., 2019). From the present study it can be concluded that $C$. etunicatum is the best AMF for improving the growth of broom grass. As far as we are aware, this is the first report on screening and selecting the best AMF for inoculating broom grass. This is being validated now under field conditions.

\section{ACKNOWLEDGEMENTS}

The authors would like to thank SEED Division, Department of Science and Technology, GOI for financial assistance to carry out this work.

\section{REFERENCES}

Anuradha, J., Kumar, A., Saxena, R. K., Kamalvanshi, M. and Chakravarty, N. 2012. Effect of arbuscular mycorrhizal inoculations on seedling growth and biomass productivity of two bamboo species. Ind. $J$. Microbiol. 52: 281-285.

Anuroopa, N. and Bagyaraj, D. J. 2015. Influence of different AM fungi on the growth, nutrition and withanolide concentration of Withania somnifera. Med PlantsInt. J. Phytomed. Rel. Indus. 7:272-276.

Ashwin, R., Bagyaraj, D.J. and Mohan Raju, B. 2018. Evaluation of different arbuscular mycorrhizal fungi for selecting the best for inoculating soybean cultivars MAUS 2 and MAUS 212. Pertanika $J$. Trop. Agric. Sci. 41: 1587-1598.
Ashwin, R., Bagyaraj, D.J. and Mohan Raju, B. 2019. Symbiotic response of drought tolerant soybean varieties, DSR 2 and DSR 12 to different arbuscular mycorrhizal fungi. Proc. Natl. Acad. Sci., India, Sect. B Biol. Sci. 89: 649-655.

Bagyaraj, D. J. 2015. Status Paper on Arbuscular Mycorrhizal Fungi. In: Advances in Mycorrhiza and Useful Microbes in Forestry (Eds.: Harsh, N.S. and Kumar, A.). ICFRE State of Knowledge Series 2. Greenfields Publishers, Dehra Dun, 21-37.

Bagyaraj, D. J. and Sturmer, S. L. 2008. Arbuscular mycorrhizal fungi (AMF). In: $A$ handbook of Tropical Soil Biology: Sampling and Characterization of Belowground Biodiversity (Eds.: Moreira, F. M. S., Huising, J. E. and Bignell, D. E.). Earthscan Pub., London, 131- 147.

Bagyaraj, D.J, Sharma, M.P, and Maiti, D. 2015. Phosphorus nutrition of crops through arbuscular mycorrhizal fungi. Curr. Sci. 108: 1288-1293.

Bagyaraj, D.J. 2014. Mycorrhizal fungi. Proc. Indian Natl. Sci.Acad. 80: 415-428.

Berruti, A., Lumini, E., Balestrini, R. and Bianciotto, V. 2016. Arbuscular mycorrhizal fungi as natural biofertilizers: Let's benefit from past successes. Front. Microbiol. 6:1559.

Bhale, U. N. 2018. Arbuscular mycorrhizal fungi (AMF) status and diversity of weedy plants in degraded land. Int. J. Plant Pathol. 9: 1-8.

Bonfante, P. 2018. The future has roots in the past: the ideas and scientists that shaped mycorrhizal research. New Phytol. 220: 982-995.

Bücking, H. and Kafle, A. 2015. Role of arbuscular mycorrhizal fungi in the nitrogen uptake of plants: current knowledge and research gaps. Agronomy 5: 587-612.

Garcés-Ruiz, M., Senés-Guerrero, C., Declerck, S. and Cranenbrouck, S. 2017. Arbuscular mycorrhizal fungal community composition in Carludovica palmata, Costus scaber and Euterpe precatoria from weathered oil ponds in the Ecuadorian Amazon. Front. Microbiol. 8: 2134.

Giovannetti, M. and Mosse, B. 1980. An evaluation of techniques to measure vesicular arbuscular infection in roots. New Phytol. 84: 489-500.

Hashem, A., Abd_Allah, E. F., Alqarawi, A. A., Al-Huqail, A. A., Wirth, S. and Egamberdieva, D. 2016. The interaction between arbuscular mycorrhizal fungi and endophytic bacteria enhances plant growth of Acacia gerrardii under salt stress. Front. Microbiol. 7:1089.

Hatchell, G. E., Berry, C. R., and Muse, H. D. 1985. Nondestructive indices related to aboveground biomass of young loblolly and sand pines on ectomycorrhizal and fertilizer plots. For. Sci. 31: 
419-427.

Jackson, M.L. 1973. Soil chemical analysis. Prentice Hall (India) Pvt. Ltd., New Delhi, 498 pp.

Jyothi, E. and Bagyaraj, D. J. 2016. Symbiotic Response of Ocimum sanctum to different arbuscular mycorrhizal fungi. Kavaka 47: 42-45.

Ortas, I. 2010. Effect of mycorrhiza application on plant growth and nutrition uptake in cucumber production under field conditions. Spanish J. Agric. Res. 8: 116122.

Philips, J. M. and Hayman, D. S. 1970. Improved procedures for clearing roots and staining parasitic and vesicular mycorrhizal fungi for rapid assessment of infection. Trans. Br. Mycol. Soc. 55:158-161.
Ramanaiah, K., Prasad, A. R. and Reddy, K. H. C. 2012. Thermal and mechanical properties of waste grass broom fibre-reinforced polyester composites. Mater. Design 40: 103-108.

Surendran, U. and Vani, D. 2013. Influence of arbuscular mycorrhizal fungi in sugarcane productivity under semiarid tropical agro ecosystem in India. Int. J. Plant Production 7: 269-278.

Thilagar, G. and Bagyaraj, D. J. 2015. Influence of different arbuscular mycorrhizal fungi on growth and yield of chilly. Proc. Indian Natl. Sci. Acad. 85: 71-75. 